\title{
A PHAGE-INHIBITOR FOR THE SWARMING OF PROTEUS
}

\author{
S. T. Roux and P. C. Appelbaum \\ Department of Microbiology, University of Pretoria, Pretoria, South Africa
}

SWAR MING Proteus may constitute a problem in obtaining pure cultures of other organisms. A wide variety of chemical and physical methods have been employed to inhibit swarming (Krämer and Koch, 1931; Holman, 1957; Hoeniger, 1965; Kopp, Müller and Lemmer, 1966; Brogan, Nettleton and Reid, 1971). These methods are unsatisfactory in that they may prevent the growth of organisms. Schuback (1926) developed an $\mathrm{H}$-antiserum-agar that inhibited the swarming of proteus strains without influencing growth. For a number of reasons, this method was also unsatisfactory for routine use (Dettling, 1932).

The addition of phage to a liquid culture of Proteus OX19 by Sukneff, Milaschewskaja and Modjaew (1929) inhibited its motility. Dettling obtained inhibition of swarming by incorporating a proteus phage into agar plates. The phages used by these workers were not further characterised. Brandis and Schwarzrock (1956) isolated non-motile phage-resistant mutants by incubating four different phages with motile proteus strains in liquid medium. In confirmation of the work of Dettling, these authors found that the addition of phage to agar plates inhibited the swarming of most proteus strains. The above phages were not flagellotropic, were effective on a wide range of proteus strains and had no effect on the viability of organisms.

Phage $\chi_{7}$ is a flagellotropic phage for the Proteus-Providence group with a wide host range. The addition of a drop of phage to a sensitive motile strain immediately immobilises it (Appelbaum, Hugo and Coetzee, 1971). We investigated the use of this phage to inhibit the swarming of Proteus from clinical material and thus to facilitate the recovery of the accompanying organisms.

\section{MATERIALS AND METHODS}

Media. Difco Tryptose Blood Agar Base with the addition of defibrinated horse blood was used for the cultivation of bacteria and the medium of Marmion (1967) for the cultivation of mycoplasmas.

Phage. Phage $\chi_{7}$ was propagated on Proteus mirabilis strain 13 (Coetzee and Sacks, 1960) by the agar overlay method of Swanstrom and Adams (1951), and was stored at $4^{\circ} \mathrm{C}$. The phage was added to the medium, immediately after the addition of the blood, at a final concentration of $1 \times 10^{10}$ plaque-forming units (p.f.u.) per ml. Alternatively, $0.2 \mathrm{ml}$ of phage (titre $1 \times 10^{11}$ p.f.u. per $\mathrm{ml}$ ) was spread on the surface of blood-agar plates. Only surfacespread phage was used on mycoplasma medium.

Bacteria. The following were isolated from clinical material: Proteus mirabilis (57 strains), Pr. vulgaris (11 strains), Pr. rettgeri, Pr. morganii, Streptococcus pyogenes (2 strains each), Serratia marcescens, Escherichia coli (10 strains each), Pseudomonas aeruginosa, Alcaligenes faecalis, Staphylococcus aureus (5 strains each), Clostridium perfringens (4 strains), Mycoplasma orale and $M$. salivarium (1 strain each). Overnight broth cultures of the organisms were prepared; each of the swarming Pr. mirabilis and Pr. vulgaris strains was mixed in equal volume with each of the other organisms and then streaked for single colonies on the appropriate medium with phage incorporated or spread on the surface. Media without phage served as controls. Blood-agar plates were incubated for $18 \mathrm{hr}$ at $37^{\circ} \mathrm{C}$. Mycoplasma cultures were incubated anaerobically for 4 days at $37^{\circ} \mathrm{C}$.

\section{RESULTS}

Plates with phage incorporated inhibited the swarming of 83.6 per cent. of $P r$. mirabilis and 45.3 per cent. of $P r$. vulgaris strains. Plates with surface phage were more effective.

Received 30 Dec. 1971; accepted 9 Feb. 1972.

J. MED. MICROBIOL, - VOL. 5 (1972) 
These inhibited 97 per cent. of Pr. mirabilis and 85.6 per cent. of Pr. vulgaris strains. Control plates were covered with proteus swarms and accompanying organisms could not be recovered. Susceptible proteus strains formed non-swarming colonies and the phage apparently set up a temperate relationship with them. Accompanying strains could invariably be recovered as single colonies. Plates with phage incorporated and stored at $4^{\circ} \mathrm{C}$ were suitable for use up to $1 \mathrm{wk}$. High-titre stocks of phage were easily prepared and maintained their titres indefinitely at $4^{\circ} \mathrm{C}$.

\section{Discussion}

These procedures appear to have advantages over methods previously used. The swarming of more than 85 per cent. of proteus strains was prevented without the organisms being killed. The phage did not affect the viability of the accompanying organisms, which could invariably be isolated in pure culture. Addition of phage to the surface of the plates appears to have advantages, because this can be done immediately before inoculation.

This method is of particular value in isolating mycoplasmas because the swarming of Proteus is a particular problem on media with a low agar concentration that must be incubated for a long time.

\section{SUMMARY}

A method is described of inhibiting the swarming of Proteus in cultures of clinical material by the use of a flagellotropic phage, which has a wide range of activity on members of the Proteus-Providence group. The sensitive proteus strains formed isolated colonies, and the accompanying organisms could be obtained in pure culture.

This work was aided by grants to Professor J. N. Coetzee from the South African Medical Research Council.

\section{REFERENCES}

Appelbaum, P. C., Hugo, N., And Coetzee, J. N. 1971. A flagellar phage for the ProteusProvidence group. J. Gen. Virol., 13, 153.

Brandis, H., AND Schwarzrock, A. 1956. Uber Proteus-Bakteriophagen. Zentbl. Bakt. ParasitKde, I Abt. Orig., 165, 226.

Brogan, T. D., Netrleton, Jeanne, and Reid, Carolyn 1971. The swarming of proteus on semisynthetic media. J. Med. Microbiol., 4, 1.

CoEtzee, J. N., AND SACKs, T. G. 1960. Transduction of streptomycin resistance in Proteus mirabilis. J. Gen. Microbiol., 23, 445.

DetTling, H. 1932. Einfluss eines Proteusbakteriophagen auf das Schwärmvermögen von Proteusbazillen. Arch. Hyg. Bakt., 108, 359.

Hoeniger, Judith F. M. 1965. Influence of $p \mathrm{H}$ on Proteus flagella. J. Bact., 90, 275.

Holman, R. A. 1957. The use of sulphonamides to inhibit the swarming of Proteus. $J$. Path. Bact., 73, 91.

Kopp, R., Müller, J., AND Lemme, Renate 1966. Inhibition of swarming of Proteus by sodium tetradecylsulfate, $\beta$-phenethyl alcohol, and $p$-nitrophenylglycerol. Appl. Microbiol., 14, 873.

KräMer, Elisabeth, AND Koch, F. Elizabeth 1931. Hemmung des Schwärmens der Proteuskolonien durch Chloralhydrat, verglichen mit der Hemmung durch Dextrose, $42^{\circ}$-Züchtung, Phenol, Natriumchlorid, Wismut, Esbachs Reagenz, Malachitgrün, Galle und Kupfersulfat. Zentbl. Bakt. ParasitKde, I Abt., Orig., 120, 452.

MARMION, B. P. 1967. In Recent advances in medical microbiology, edited by A. P. Waterson, London, p. 170.

SCHUBACK, A. 1926. Zur Technik der bakteriologischen Untersuchung von proteushaltigem Material. Klin. Wschr., 5, 67.

SuknefF, W., Milaschewskaja, W., and Modjaew, P. 1929. Einfluss des Bakteriophagen auf die Biologie der Mikroorganismen. Sib. med. Zh., no. 6. Abstracted in Zentbl. Bakt. ParasitKde, I Abt., Ref., 1930, 97, 191.

Swanstrom, M., AND Adams, M. H. 1951. Agar layer method for production of high titer phage stocks. Proc. Soc. Exp. Biol. Med., 78, 372.

Vol. 5, No. 2, May 1972, was issued on 15.5.72. 